AperTO - Archivio Istituzionale Open Access dell'Università di Torino

\title{
Vulval lichen planus in the practice of a vulval clinic.
}

\section{This is the author's manuscript}

Original Citation:

Availability:

This version is available http://hdl.handle.net/2318/38336

since

Terms of use:

Open Access

Anyone can freely access the full text of works made available as "Open Access". Works made available under a Creative Commons license can be used according to the terms and conditions of said license. Use of all other works requires consent of the right holder (author or publisher) if not exempted from copyright protection by the applicable law. 

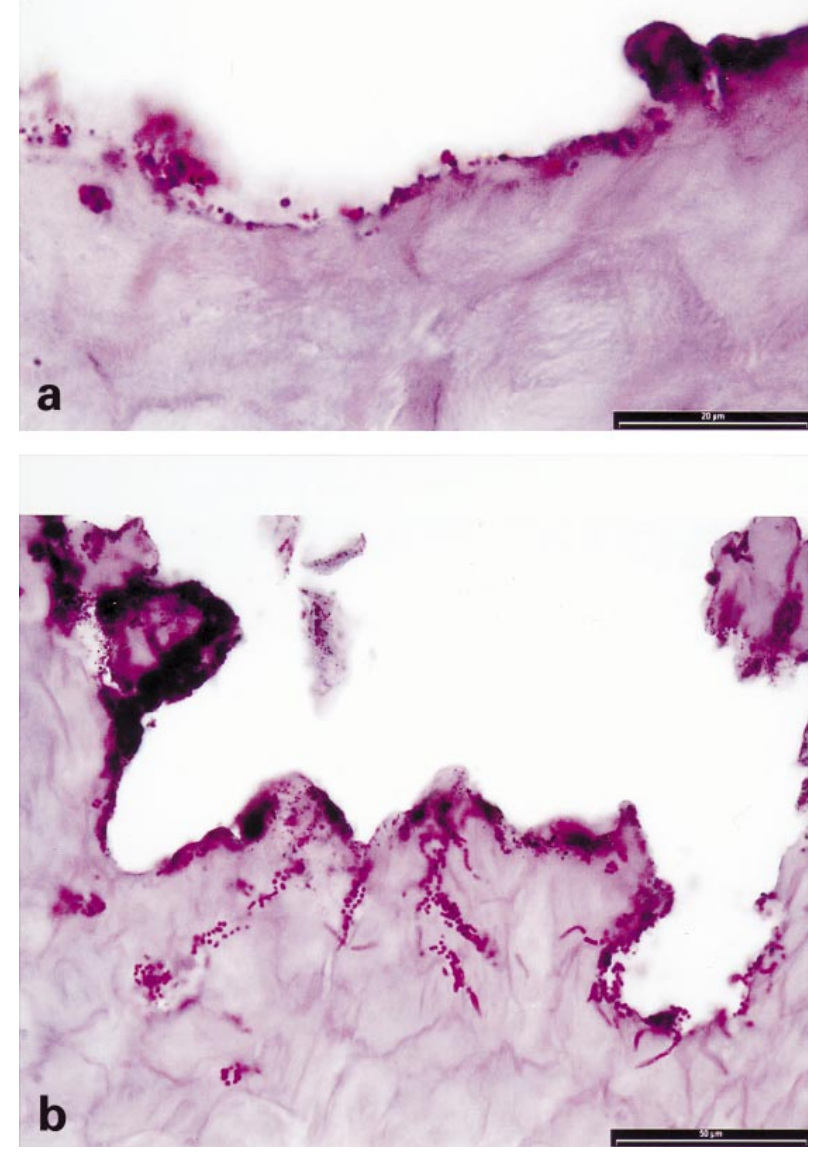

Figure 1. (a) Minor type of keratolysis sulcata with coccoid bacteria only at the surface of the horny layer and pitted lysis of the keratin. (b) Major type with intracellular coccoid elements, septate hyphae and keratolytic rings (periodic acid-Schiff).

cause keratolysis sulcata apart from those already known, and also whether this illness actually represents a clear-cut, unique entity.

Department of Dermatology and Venereology, Martin-Luther-University Halle-Wittenberg,

J.WOHLRAB Ernst-Kromayer-Str. 5-6, D-06097 Halle D.ROHRBACH W.C.MARSCH

(Saale), Germany

E-mail: johannes.wohlrab@medizin.uni-halle.de

\section{References}

1 Takama H, Tamada Y, Yano K et al. Pitted keratolysis: clinical manifestations in 53 cases. Br J Dermatol 1997; 137: 282-5.

2 Gill Ka Jr, Buckels LJ. Pitted keratolysis. Arch Dermatol 1968; 98 : 1107-12.
3 Seghal VN, Ramesh V. Crateriform depression - an unusual clinical expression of pitted keratolysis. Dermatologica 1983; 166: 209-11.

4 Hänel H, Kalisch J, Keil M et al. Quantification of keratinolytic activity from Dermatophilus congolensis. Med Microbiol Immunol 1991; 180: 45-51.

5 Rubel LR. Pitted keratolysis and Dermatophilus congolensis. Arch Dermatol 1972; 105: 584-6.

6 Amadi EN, Alderson G. Menaquinone composition of some micrococci determined by high performance liquid chromatography. J Appl Bacteriol 1991; 70: 517-21.

7 Nordstrom KM, McGinley KJ, Cappiello L et al. Pitted keratolysis the role of Micrococcus sedentarius. Arch Dermatol 1987; 123: $1320-5$.

8 Tilgen W. Pitted keratolysis (keratolysis plantare sulcatum). Ultrastructural study. J Cutan Pathol 1979; 6: 18-30.

9 Takama H, Tamada Y, Yokochi K, Ikeya T. Pitted keratolysis: a discussion of two cases in non-weight-bearing areas. Acta Derm Venereol (Stockh) 1998; 78: 225-6.

\section{Vulval lichen planus in the practice of a vulval clinic}

SIR, The aim of the present study was to present the prevalence of vulval lichen planus in our Vulval Clinic and to compare our clinical and histological findings with the few reports available in the literature.

The study group consisted of 125 cases of vulval lichen planus histologically diagnosed among 3350 women given a vulval biopsy during the period 1986-99 at the Vulval Clinic of the Department of Gynaecology and Obstetrics of the University of Turin. For each patient, data regarding general, gynaecological and vulval history along with vulval gross appearance were obtained from the medical records. The symptomatology was described as absent, pruritus, burning, or pruritus and burning. With the aim of standardizing the various non-specific clinical descriptions, the vulval gross appearance was categorized into three simple clinical categories: white, erosive, or white and erosive. Similarly, the localization of the disease was categorized as cutaneous, mucosal or mucocutaneous.

The median age of the patients was 58 years (range 16-83). The clinical features of the 125 cases correlated with the histological findings are reported in Table 1. Symptoms were absent in $10 \cdot 3 \%$ (12 of 125) of the patients. Pruritus, burning, and pruritus and burning were present, respectively, in $40 \cdot 8 \%$ ( 51 of 125 ), $4 \cdot 8 \%$ (six of 125 ) and $44 \cdot 8 \%$ (56 of 125 ) of the patients. A buccal examination was performed in 105 women, and oral involvement consisting of lacy white plaques was noted in seven $(6 \cdot 6 \%)$.

To our knowledge, this is the first study addressing the prevalence of vulval lichen planus, histologically confirmed, in the practice of a vulval clinic. The $3 \cdot 7 \%$ prevalence of this dermatosis in our series underlines that vulval lichen planus is not so rare as usually reported. In the same series the prevalence of the well-defined vulval diseases invasive squamous cell carcinoma, vulval intraepithelial neoplasia grade $2-3$ and lichen sclerosus were $4 \cdot 1 \%$ (139 of 3350), $2 \cdot 0 \%$ (69 of 3350 ) and $13 \cdot 9 \%$ (468 of 3350 ), respectively.

The lack of terminological agreement makes it difficult to compare our clinical descriptions with those in the literature, 
Table 1. Clinical and histological findings in 125 women affected by vulval lichen planus (LP)

\begin{tabular}{|c|c|c|c|c|c|c|}
\hline \multirow[b]{2}{*}{ Clinical finding } & \multirow[b]{2}{*}{ No. of cases } & \multicolumn{5}{|c|}{ Histological findings } \\
\hline & & Typical LP & Erosive LP & Hypertrophic LP & Atrophic LP & Planopilaris LP \\
\hline \multicolumn{7}{|c|}{ Gross appearance } \\
\hline White & $83(66 \cdot 4 \%)$ & 61 & - & 9 & 13 & - \\
\hline Erosive & $22(17 \cdot 6 \%)$ & 14 & 2 & - & 5 & 1 \\
\hline White-erosive & $20(16 \cdot 0 \%)$ & 16 & 1 & - & 3 & - \\
\hline \multicolumn{7}{|l|}{ Localization } \\
\hline Cutaneous & $69(55 \cdot 2 \%)$ & 48 & 2 & 6 & 12 & 1 \\
\hline Mucosal & $24(19 \cdot 2 \%)$ & 20 & - & 1 & 3 & - \\
\hline Mucocutaneous & $32(25 \cdot 6 \%)$ & 23 & 1 & 2 & 6 & - \\
\hline Total & 125 & 91 & 3 & 9 & 21 & 1 \\
\hline
\end{tabular}

where erosive disease accounts for $71 \%$ of vulval lichen planus compared with $29 \%$ of patients who have 'typical' lesions (Table 2). Assuming that our definition 'white lesions' can be interpreted as being synonymous with 'typical lesions', pure erosive lesions in our series accounted for $17 \cdot 6 \%$ of vulval lichen planus lesions, compared with $82.4 \%$ with white lesions $(66 \cdot 4 \%$ with white lesions $+16 \cdot 0 \%$ with whiteerosive lesions). In addition, vaginal involvement was reported in $64 \%$ of the cases from the literature listed in Table 2, while in our series no patients were demonstrated to have vaginal involvement despite a colposcopic examination performed in all cases.

From the review of the literature we found no comparison between clinical appearance and histological diagnosis, probably because there is a lack of clear separation between clinical and histological terminology. This comparison in our series (Table 1) showed a relatively good correlation between 'white lesions' and histologically typical lichen planus. No correlation was found between clinically erosive and histologically erosive lichen planus. This suggests that the term 'erosive' probably has different significance when used by the clinician and the pathologist. We believe that there is the need to integrate gynaecological, dermatological and histological knowledge to achieve two separate classifications, one clinical and the other histological, for a better definition of vulval lichen planus.

Finally, we believe that a gynaecologist dealing with vulval disease must be aware of the existence of vulval lichen planus. In addition, before taking a vulval biopsy a careful examination of other mucous membrane surfaces should be performed.
A photograph of the lesion may help the pathologist in arriving at the correct diagnosis.

Department of Gynaecology and Obstetrics, L.MicheLetTI University of Turin,

Largo Mentana 11,

10133 Turin, Italy

*Department of Pathology,

Sant'Anna Hospital, Turin, Italy

M.Preti

F.Bogliatto

M.C.ZanotTo-Valentino

B.GHiringhello*

M.Massobrio

\section{References}

1 Weber FP. A note on lichen planus of the vulva. Br J Dermatol 1927; 36: $521-2$.

2 Hewitt J, Pelisse M, Lessana-Leibowitch M et al. Le syndrome vulvovagino-gingival: nouveau groupement caractéristique du lichen plan érosif plurimuqueux. Rev Stomatol Chir Maxillofac 1985; 86: $57-65$.

3 Soper DE, Patterson JW, Hurt WG et al. Lichen planus of the vulva. Obstet Gynecol 1988; 72: 74-6.

4 Edwards L, Friedrich EG. Desquamative vaginitis: lichen planus in disguise. Obstet Gynecol 1988; 71: 832-6.

5 Ridley CM. Chronic erosive vulval disease. Clin Exp Dermatol 1990; 15: 245-52.

6 Mann MS, Kaufman RH. Erosive lichen planus of the vulva. Clin Obstet Gynecol 1991; 34: 605-13.

7 Eisen D. The vulvovaginal-gingival syndrome of lichen planus. The clinical characteristics of 22 patients. Arch Dermatol 1994; 130: 1379-82.

8 Lewis FM, Shah M, Harrington CI. Vulval involvement in lichen planus: a study of 37 women. Br J Dermatol 1996; 135: 89-91.

Table 2. Cases of lichen planus (LP) involving the vulva, from a review of the literature

\begin{tabular}{|c|c|c|c|c|c|c|c|}
\hline \multirow[b]{2}{*}{ Author } & \multirow[b]{2}{*}{ Year } & \multirow[b]{2}{*}{ No. of cases } & \multicolumn{2}{|c|}{ Clinical diagnosis } & \multirow[b]{2}{*}{ Biopsy } & \multirow{2}{*}{$\begin{array}{c}\text { Histological } \\
\text { confirmation }\end{array}$} & \multirow{2}{*}{$\begin{array}{c}\text { Vaginal } \\
\text { involvement }\end{array}$} \\
\hline & & & Typical & Erosive & & & \\
\hline Weber $^{1}$ & 1927 & 1 & 1 & 0 & - & - & 1 \\
\hline Hewitt et al. ${ }^{2}$ & 1985 & 19 & 0 & 19 & $13 / 19$ & $10 \mathrm{LP}$ & 11 \\
\hline Soper et $a l^{3}$ & 1988 & 4 & 0 & 4 & $4 / 4$ & $4 \mathrm{LP}$ & 3 \\
\hline Edwards \& Friedrich ${ }^{4}$ & 1989 & 7 & 1 & 6 & $7 / 7$ & $7 \mathrm{LP}$ & 6 \\
\hline Ridley $^{5}$ & 1990 & 17 & 1 & 16 & $17 / 17$ & $17 \mathrm{LP}$ & 7 \\
\hline Mann et al. ${ }^{6}$ & 1991 & 17 & 9 & 8 & $17 / 17$ & $4 \mathrm{LP}$ & 13 \\
\hline Eisen $^{7}$ & 1994 & 22 & 6 & 16 & $6 / 22$ & $6 \mathrm{LP}$ & 10 \\
\hline Lewis et al. ${ }^{8}$ & 1996 & 19 & 13 & 6 & $19 / 19$ & $19 \mathrm{LP}$ & - \\
\hline Total & & 106 & $31(29 \cdot 2 \%)$ & $75(70 \cdot 7 \%)$ & $83 / 105(79 \cdot 0 \%)$ & $67 / 105(63 \cdot 8 \%)$ & $51(64 \cdot 0 \%)$ \\
\hline
\end{tabular}

